\title{
PERLINDUNGAN HUKUM TERHADAP PEKERJA ANAK DI BAWAH UMUR BERDASARKAN HUKUM KETENAGAKERJAAN DI INDONESIA DI PERUSAHAAN TEMBAKAU PERAHU LAYAR AMPENAN TAHUN 2015
}

\author{
Dr. Hj. Maemunah, S.Pd.,MH \& Nur Hamzah \\ (Dosen Perserikatan Muhammadiyah)
}

\section{INFO ARTIKEL}

Riwayat Artikel:

Diterima: 03-09-2016

Disetujui: 30-09-2016

\section{Kata Kunci:}

Perlindungan Hukum, Anak dibawah umur, Hukum Ketenagakerjaan

\section{A. LATAR BELAKANG}

Di Indonesia setelah proklamasi kemerdekaan Rsepublik Indonesia Tanggal 17 Agustus 1945, kaum wanita telah ditegaskan bahwa kedudukan dan haknya sama dengan kaum pria, baik sebagai penduduk maupun sebagai warga Negara Republik Indonesia. Persamaan hak tersebut dicantumkan dalam Undang-Undang Dasar 1945, yakni di dalam: Pasal 27 ayat (1) "Segala warga biasa Negara bersama kedudukkannya didalam hukum dan pemerintahan dan wajib menjunjung hukum dan pemerintah itu dengan tidak terkecualinya". (2) "Tiaptiap warga Negara besar berhak atas pekerjaan dan penghidupan yang layak bagi kemanusiaan".

Di Indonesia, usia minimum untuk diperbolehkan bekerja adalah lima belas tahun, namun demikian, banyak anak perempuan atau laki-laki yang mulai bekerja ketika usia mereka masih beberapa tahun di bawahnya. Hal ini diatur dalam Undang-Undang No.4 Tahun 1979 tentang kesejatraan anak.Konsideran itu mengacu pada pasal 34 Undang-Undang Dasar 1945 yang mengatakan fakir miskin dan anak terlantar dipelihara oleh negara. Dengan demikian apabilah ketentuan pasal 34 UUD 1945 diberlakukan secara konsekuen, maka kehidupan anak terutama fakir miskin dan anak terlantar akan terjamin.

Kasus tenaga kerja di Indonesia, memang sangat banyak yang terjadi di dunia.Salah satunya Negara Indonesia, khususnya Papua.Indonesia adalah sebuah negara yang sedang berkembang, dan memiliki cukup banyak penduduk. Maka, sering banyak terjadi kasus dalam mempermasalahkan tentang tenaga kerja. Faktorfaktor yang menyebabkan terjadinya berbagai kasus tenaga kerja di Indonesia. Beberapa contoh yang terjadi adalah :Kurangnya Lowongan Kerja, dan Kurangnya Penempatan Skill yang tepat dalam setiap Pekerjaan. Pertama, Kurangnya lowongan kerja, dimana kebanyakan kasus tenaga kerja yang terjadi diakibatkan oleh sedikitnya perusahaan yang didirikan oleh pemerintah. Kebanyakan perusahaan yang didirikan oleh pemerintah umumnya lebih memilih tenaga kerja yang berpendidikan atau terdidik. 
12 CIVICUS I Pendidikan Pancasila dan Kewarganegaraan Sedangkan di Indonesia masih sangat banyak masyarakat yang sudah termasuk dalam angkatan kerja belum mendapatkan pendidikan yang layak . Kedua, Kurangnya penempatan skill yang tepat dalam setiap Pekerjaan, dimana kebanyakan perusahaan yang didirikan oleh pemerintah membutuhkan tenaga ahli dalam berbagi bidang.

Di Indonesia, khususnya di Jawa Tengah, masalah perusahaan rokok dan tenaga kerja yang mengakibatkan bangkrutnya pabrik-pabrik kecil dan banyaknya pengagguran di Indonesia. Pengusaha rokok di daerah kita kini berguguran, mereka yang dicap ilegal didatangi polisi, dirampas alat produksinya, dan rokok disita. Namun begitu pabrik rokok ilegal itu hilang, muncul pabrik rokok kecil baru dengan izin resmi dari pemerintah. Dan ternyata itu milik perusahaan rokok besar dengan merek yang mendunia. Fakta bahwa penerimaan negara dari cukai rokok pada 2009 bernilai Rp55 triliun, industri rokok menyerap sedikitnya enam juta tenaga kerja, mereka juga memperjuangkan hak hidup pabrik rokok kecil, dan sebagainya.

Kasus tenaga kerja di Indonesia khususnya di PT Freeport Inonesia, Bukan Sekedar Masalah Renegosiasi Tapi Menegakkan Kedaulatan RI.Sudah 44 tahun aktivitas pertambangan emas PT Freeport-McMoran Indonesia (Freeport) bercokol di tanah Papua.Namun selama itu pula kedaulatan negara ini terus diinjak-injak oleh perusahan asing tersebut.Dibandingkan PT Freeport yang memiliki tenaga kerja dan modal tentu posisi tawar pemerintah saat itu masih kecil.

Komisi IX DPR RI akan membentuk Tim untuk penyelesaian kasus ketenagakerjaan PT Freeport Indonesia yang terdiri dari perwakilan Komisi IX DPR RI, Kementerian Tenaga Kerja dan Transmigrasi RI serta pihak-pihak terkait lainnya. Tim ini akan menyelesaikan kasus yang terjadi antara pekerja dengan management PT Freeport Indonesia. Ketua Komisi IX DPR RI dalam Konferensi Pers di Gedung DPR RI, Ia menyatakan turut prihatin dan berbela sungkawa atas kejadian penembakan terhadap karyawan PT Freeport Indonesia yang mengakibatkan tewasnya Piter Ayami Seba pada aksi massa 10 Oktober 2011. Komisi IX DPR RI mendesak PT Freeport Indonesia untuk memenuhi hak-hak normatif para pekerja serta tidak mengganti pekerja dengan pekerja lain selama melakukan mogok kerja sesuai dengan amanat UU No.13 Tahun 2003.

Dinas Tenaga Kerja Provinsi Nusa Tenggara Barat mencabut izin sedikitnya tiga Perusahaan Jasa Tenaga Kerja Indonesia (PJTKI).Pencabutan ini sesuai dengan rekomendasi Departemen Tenaga Kerja dan Transmigrasi, karena perusahaan tersebut dianggap kerap melanggar aturan ketenagakerjaan. Perusahaanperusahaan yang dicabut izinnya adalah PT L Karim Makmur Sentosa dan PT Ivan Margatama, yang resmi dicabut April lalu dan PT Karya Antar Bangsa Sejati, yang rekomendasi pencabutannya turun pada bulan Juli ini. Semuanya membuka kantor cabang di NTB. "Dua perusahaan resmi pencabutannya. Satu lagi, menyusul," tegas Lalu Burhanuddin, Kepala Sub Dinas Penempatan TKI, Dinas Tenaga Kerja NTB, di kantornya, di Mataram, Senin(26/7) siang.Pencabutan izin PJTKI itu, melengkapi tindakan Dinas Tenaga Kerja NTB, yang pada 2003, juga menindak 15 PJTKI yang dianggap kerap melanggar aturan ketenagakerjaan. Pelanggaran yang dimaksud antara lain, memanipulasi umur calon TKI/TKW, mengirimkan calon di bawah umur, memalsukan dokumen seperti surat-surat syarat
Vol. 4, No. 2, September 2016, hal 11-21

kesehatan hingga visa kerja. "Yang lebih mencolok, ada manipulasi laporan jumlah pengiriman tenaga kerja.Misalnya dilaporkan calon yang berangkat 50 orang, tapi ternyata ada 75 orang yang dikirim. Ini sudah keterlaluan,"tegas Burhanudin.Terkait dengan kasus pengiriman calon TKW di bawah umur seperti yang terjadi di Kabupaten Sumbawa dua pekan lalu, Burhanudin, mengaku dirinya telah mendapatkan data tersebut. Tapi untuk menindaknya perlu ada bukti-bukti yang akurat, seperti bukti-bukti dokumen dan kasuskasus PJTKI yang ditangan polisi. Kepala Dinas Tenaga Kerja NTB Sirojul Munir mengatakan, sekarang ini jumlah PJTKI di NTB 97 perusahaan, lima diantaranya berkantor pusat di NTB. Instansinya telah melakukan pengetatan izin membuka cabang di NTB dengan alasan jumlahnya PJTKI sudah terlalu banyak."Terutama perusahaan yang punya kerja pengiriman ke Timur Tengah. Karena banyak kasus dan kita kesulitan mengawasi mereka," tegasnya saat ditemui di kantor DPRD NTB, Senin,siang. Kasus-kasus yang berkaitan dengan perlindungan.TKW/TKI kini menjadi pembahasan para aktivis LSM buruh migran.Agendanya diantaranya mendorong Pemerintah Provinsi NTB menyetujui Peraturan Daerah untuk perlindungan TKI/TKW.Kendati usulan itu mendapat lampu hijau dari Komisi E DPRD NTB, tapi Gubernur NTB Lalu Serinata, menolaknya.Alasan gubernur menolak Perda tersebut adalah, karena UU tentang Perlindungan Buruh Migran belum disetujui pemerintah pusat.Gubernur mengkuatirkan terjadi tumpang tindih jika NTB menyetujui Perda tentang Perlindungan Buruh Migran.

Lima orang pekerja di perusahaan Tembakau Perahu Layar Ampenan di berhentikan karena bergabung dengan serikat pekerja. Perusahaan Tembakau memiliki peraturan terhadap pekerja. Pekerja atau buruh menuntut hak mereka yaitu mengenai upah, upah yang diberikan sebelumnya Rp 25.000 \%/ hari, padahal upah minimum kabupaten sebesar Rp. 40.00o/ hari dan biaya Jamsostek yang 100\% di bebankan kepada pekerja. Sekarang pekerja atau buruh telah menikmati upah yang sesuai dengan upah minimum kabupaten dan memiliki Jamsostek yang dibayarkan oleh perusahaan.

Kesuksesan para pekerja dalam menuntut hak kerja mereka, para perusahaan banyak mengalami pelanggaran hak-hak pekerja dalam perusahaan , diantaranya adalah pembagian upah, yang menganut sistem bagi hasil. Apabila pekerja tidak masuk akan di kenakan denda sebanyak Rp. 200.00o/ hari kecuali tidak masuk kerja karena sakit. Tunjangan hari raya pun tidak pernah diberikan kepada pekerja. Dan masalah lain adalah mengenai tidak diberikannya fasilitas Jamsostek, sehingga apabila terjadi kecelakaaan pekerja harus menanggung sendiri biayanya.

Akan tetapi, pejuangan pekerja lebih berat karena perusahaan sudah semakin pintar dalam berkelit .Mereka tidak mempunyai perjanjian kerja bersama (PKB) sesuai printah dan peraturan di kemukakan secara lisan sehingga pekerja tidak memiliki bukti tertulis yang bisa dijadikan senjata untuk melawan perusahaan seperti halnya yang dilakukan oleh pekerja di perusahaan yang lainnya.

Pada dasarnya anak-anak yang masih yang dibawah umur hanya memiliki tugas untuk belajar dan menyelesaikan studinya namun demikian karena keadaan ekonomi yang mendesak keluarga mereka pada akhirnya memaksa anak dibawah umur dari kalangan 
tidak mampu untuk ikut belajar dan mendapatkan imbalan agar memenuhi kebutuhan hidup keluarga mereka. Dalam perkembangannya, pekerjaan anak ini di mulai dipastikan mendapat perlindungan oleh Undangundang No.23 Tahun 2002 tentang perlindungan anak. Dengan prinsip-prinsip dasar Hak anak yang diatur dalam Undang-undang No. 23 Tahun 2002, dimana hak-hak itu meliputi, (a) Non diskriminasi, (b) Kepentingan yang terbaik bagi anak, (c) Hak untuk hidup, kelansungan untuk hidup dan perkembangannya, (d) penghargaan terhadap pendapat anak. Hal ini ditunjukan agar anak dapat memperoleh kesempatan untuk menyelesaikan studinya.Selain itu juga perlindungan juga diberikan terhadap buruh wanita. Perlindungan pada buruh wanita ini disebabkan karena wanita cendrung memiliki keadaan fisik lemah daripada kaum pria.Oleh karena itulah wanita tidak pantas untuk diberikan pekerjaan yang lebih berat daripada kaum pria.Namun dengan adanya perlindungan ini bukan berarti hambatan-hambatan yang ada dapat terselesaikan dengan mudah.Karena pada prakteknya masi banyak perusahaan yang masi saja melakukan penyimpangan terhadap pekerja anak maupun pekerja wanita.

Pada dasarnya merupakan kewajiban pemerintah pengusaha dan tenaga kerja wajib untuk mensyukurinya, karena dengan adanya pengawasan ini pemerintah selalu memperhatikan maju mundurnya perusahaan, melindungi perusahaan ini agar tidak mengalami pailit akibat ulah yang negatif yang berlansung di dalam perusahaan itu.Dengan pengawasan ini pemerintah selalu mengharapkan agar perusahaan dapat berkembang dengan baik. Dengan demikian maksud baik pemerintah itu selayaknya diimbangi oleh tenaga kerja dan perusahaan agar kegiatan sejalan dengan menaati segala ketentuan hukum dan perundangundangan yang telah dikeluarkan dan diberlakukan.

\section{B. METODE PENELITIAN}

\section{JENIS PENELITIAN}

Dalam jenis penelitian hukum terdapat dua jenis penelitian yaitu penelitian Normatif dan penelitian empiris. Dalam penelitian ini peneliti menggunakan jenis penelitian hukum empiris.

Menurut (Salim, 2014: 20), penelitian hukum empiris merupakan salah satu jenis penelitian hukum yang menganalisis dan mengkaji bekerjanya hukum dalam masyarakat. Bekerjanya hukum dalam masyarakat dapat dikaji dari tingkat efektivitasnya hukum, kepatuhan terhadap hukum, peran lembaga atau institusi hukum dalam penegakan hukum, implementasi aturan hukum, pengaruh aturan hukum terhadap masalah sosial tertentu atau sebaliknya, pengaruh masalah sosial terhadap aturan hukum.

Sementara pendekatan dalam penelitian hokum menurut Salim (2014:23) antara lain:

1. Pendekatan sosiologi hukum ialah pendekatan yang menganalisis tentang bagaimana reaksi dan interaksi yang terjadi ketika sistem norma itu bekerja dalam masyarakat.

2. Pendekatan antropologi hukum merupakan pendekatan yang mengkaji cara-cara penyelesaian sengketa, baik dalam masyarakat modern maupun masyarakat tradisional.
3. Pendekatan psikologi hukum adalah pendekatan didalam penelitian hukum empiris di mana hukum di lihat pada kejiwaan manusia. Kejiwaan manusia tentu menyangkut tentang kepatuhan dan kesadaran masyarakat tentang hukum.

Berdasarkan beberapa uraian di atas maka dalam penelitian ini peneliti menggunakan pendekatan sosiologi hukum dimana pendekatan yang menganalisis tentang bagaimana reaksi dan interaksi yang terjadi ketika aturan hukum itu berkerja pada masyarakat setempat. Adapun alasan peneliti menggunakan metode pendekatan sosiologi hukum adalah karena dalam mengungkapkan kejadian atauperistiwa sosial di lapangan tentu sumber informasi atau data yang berikan oleh informan kepada peneliti melalui wawancara atau data resmi yang berupa dokumen yang ada relefansinya dengan data atau hasil penelitian yang ingin dicapai oleh peneliti. Dalam proses penelitian ini untuk mendapatkan data dan informasi yang diperoleh langsung dalam masyarakat setempatdan tugas peneliti adalah mengkaji tentang apa yang ada dibalik yang tampak tentang Penerapan peraturan perundang-undangan dan mengkaji tentang bagaimana Perlindungan Hukum Terhadap Pekerja Perempuan dan Anak di Bawah Umur Berdasarkan Hukum Ketenagakerjaan di Perusahaan Tembakau Perahu Layar Ampenan.

\section{A. GAMBARAN LOKASI PENELITIAN}

Lokasi penelitian ini dilaksanakan di Perusahaan Tembakau Perhu Layar Ampenan, lokasi penelitian adalah dikelilingi oleh kabupaten lombok barat antara lain.

1. Sebelah Timur berbatasan dengan Komplek Taman Sejahtera

2. Sebelah Utara berbatasan dengan Gedung AlIhsan

3. Sebelah Barat berbatasan dengan Yayasan Panti Asuhan Baitul Amin. Jalan Dukuh Salah, Kelurahan Pajeruk.

4. Sebelah Selatan berbatasan dengan Komplek Taman Sejahtera Lingkungan Pajeruk Sejahtera Ampenan.

\section{JENIS DAN SUMBER BAHAN HUKUM}

1. Jenis data

Menurut (Marzuki, 2005:44) bahan hukum empiris antara lain sebagai berikut:

a. Data primer

Data primer adalah bahan resmi yang diperoleh langsung dari kepustakaan, buku peraturan perundang-undangan serta kamus hukum dan peraturan lainnya yang berkenaan dengan hal yang menjadi obyek dalam penelitian.

b. Data sekunder

Data sekunder adalah bahan hukum yang bersumber dari pendapat para ahli atau para sarjana dari berbagai literatu/pedomanr yang berhubungan dengan permasalahan yang akan diteliti

c. Data lapangan (tersier)

Data lapangan adalah data yang diperoleh langsung dari narasumber atau informan dalam masyarakat terkait dengan pokok permasalahan yang ingin dicapai dalam penelitian.

Dari penjelasan bahan hukum diatas bahwa data yang digunkan dalam penelitian ini adalah data primer 
14 CIVICUS I Pendidikan Pancasila dan Kewarganegaraa yang diperoleh peneliti secara langsung dari berbagai literatur atau perpustakaan serta peraturan perundangundangan atau kamus hukum ilmiah, yang berkaitan denganPenerapan peraturan perundang-undangan dan mengkaji tentang bagaimana Perlindungan Hukum Terhadap Pekerja Perempuan dan Anak di Bwah Umur Berdasarkan Hukum Ketenagakerjaan di Perusahaan Tembakau Perahu Layar Ampenan.

\section{a. Tehnik Penentuan Subyek}

Adapun yang menjadi subjek penelitian atau informan dalam penelitian ini adalah orang-orang yang dapat memberikan informasi tentang Perlindungan Hukum Terhadap Pekerja Anak Di Bawah Umur Berdasarkan Hukum Ketenagakerjaan Di Indonesia di Perusahaan Tembakau Perahu Layar Ampenan”.tersebut adalahpara pekerja anak, lembaga perlindungan anak di kota Mataram yang berkaitan dengan perlindungan hukum terhadap anak dan masyarakat pendukung lainnya.

Tehnik penentuan subyek dalam pendekatan hukum empiris dengan pendekatan sosiologis, penelitian menggunakan sampling yang digunakan adalah purposive sampling dan snowball sampling. Purposive sampling adalah tehnik pengambilan sampel sumber data dengan pertimbangan tertentu. Snowball sampling adalah tehnik pengambilan sampel sumber data yang pada awalnya jumlahnya sedikit lama-lama menjadi besar (Sugiyono, 2012:219).

Berdasarkan kedua tehnik penentuan subyek di atas, peneliti menggunakan tehnik purposive sampling, untuk mengumpulkan data dalam penelitian.

\section{METODE PENGUMPULAN DATA}

Metode pengumpulan data merupakan langkah yang amat penting dalam metode ilmiah, karena pada umumnya data yang dikumpulkan digunakan itu mengkaji hipotesis yang telah dirumuskan menurut Natsir M,( 2008:211).

Adapun menurut Sugiyono, (2011:63) Metode pengumpulan data merupakan suatu prosedur yang sistematik dan standar untuk memperoleh data yang diperlukan dan selalu ada hubungan antara metode pengumpulan data dengan masalah penelitian. Kegiatan pengumpulan data merupakan usaha secara operasional dalam pelaksanaan penelitian yang dapat memberikan pengaruh positif bagi pelaksanaan analisis dan interprestasi data.

Berkaitan dengan hal tersebut diatas, maka dalam penelitian ini metode pengumpulan data yang digunakan adalah sebagai berikut:

\section{a) Metode Observasi (Pengamatan)}

Observasi adalah yang dilakukan secara sengaja, sistematis, mengenai fenomena sosial dengan gejalagejala piskis untuk kemudian dilakukan pencatatan. Observasi yang digunakan oleh peneliti adalah observasi partisipatif, dimana peneliti terlihat langsung dan mengambil bagian dalam situasi dari orang-orang yang diobservasi atau melakukan pengamatan penuh terhadap obyek yang akan diobservasi. Sedangkan menurut (Suhaemin, 2008:212) Pengumpulan data dengan observasi langsung atau dengan pengamatan langsung adalah merupakan cara pengambilan data dengan menggunakan mata tanpa ada pertolongan alat standar lain untuk keperluan peneliti.

Berdasarkan jenisnya, observasi dapat di bedakan menjadi 2 (dua), bagian antara lain sebagai berikut:

a. Observasi partisipan
Vol. 4, No. 2, September 2016, hal 11-21

Observasi partisipan yaitu observasi atau pengamatan yang dilakukan dimana observer berada langsung bersama objek yang diteliti dalam lapangan.

b. Observasi non partisipan

Observasi non partisipan yaitu observasi atau pengamatan yang dilakukan tidak pada saat berlangsungnya di suatu peristiwa yang akan diteliti. Misalnya dilakukan melalui film, slide, atau foto dan lain-lain. (Nurul Zuriyah, 2008:173).

Adapun pengamatan yang digunakan dalam penelitian ini adalah Observasi non Partisipan, Observasi non partisipan yaitu, dalam proses pengamatan tersebut peneliti tidak ikut serta atau turun langsung di lapangan atau di lokasi penelitian. Dalam penelitian ini mengambil unsur-unsur terpenting dalam situasi tersebut sesuai atau mendukung kebutuhan peneliti seperti foto,slide, dan lain-lain.Sedangkan pengamatan secara langsung di lapangan tentang Penerapan peraturan perundang-undangan dan mengkaji tentang bagaimana perlindunga hukum terhadap pekerja perempuan dan anak di bawah umur berdasarkan hukum ketenagakerjaan di Perusahaan Tembakau Perahu Layar Ampenan.

\section{b) Metode Wawancara}

Metode Wawancara adalah pengumpulan data dengan cara mengajukan pertanyaan baik yang spontan, terstruktur dan tidak terstruktur yang didasarkan pada kegiatan-kegiatan penelitan. Oleh karena itu, bentuk dan variasi pertanyaan dalam penelitian harus dikaitkan dengan pengalaman/perilaku, pendapat/nilai, perasaan, pengetahuan, indra, sosial/demografi (Musawar, 2012: 23).

Menurut Soebani Ahmad (20ob: 182) Mengemukakan wawancara dapat di bedakan menjadi 2 (dua) jenis, yaitu:

a. Wawancara terstruktur

Wawancara terstruktur adalah pertanyaan dan alternatif jawaban kepdainterviewe telah di tetapkan terlebih dahulu.

b.Wawancara tidak struktur

Wawancara tidak struktur adalah wawancara yang bersifat informal, petanyaan pandangan hidup, sikap, keyakinan, subjek, atau keterangan tentang lainnya dapat diajukan kepada obyek.Wawancaran ini bersifat luwes dan biasanya direncanakan agar sesuai dengan subjek dan suasana pada saat wawancara dilaksanakan.

Berdasarkan pendapat diatas penelitian menggunakan metode wawancara tidak sutruktur, tehnik wawancara tidak sutruktur yaitu, penelitian ini langsung dalam lapangan untuk dapat mengambil apaapa yang diketahui maupun yang dialami oleh subyek dengan wawancara peneliti dapat menanyakan kepada subyek dan narasumber hal-hal yang bersifat lintas waktu yang berkaitan dengan masa lampau, masa sekarang dan masa yang akan datang. Dan yang akan diwawancara adalah karyawan dan pekerja atau buruh yang bekerja di perusahaan Tembakau Perahu Layar, sebagai nara sumber yang memiliki keahlian khusus yang berkaitan dengan masalah yang akan diteliti. Wawancara digunakan untuk mewawancarai orangorang yang dianggap dapat memberikan informasi yang dibutuhkan berkenaan dengan judul yang diangkat 
untuk diteliti dan dapat dipercaya kebenarannya. Wawancara dimaksudkan untuk mendapat informasi tentang Penerapan peraturan perundang-undangan dan mengkaji tentang bagaimana perlindungan hukum terhadap pekerja perempuan dan anak di bawah umur berdasarkan hukum ketenagakerjaan di Perusahaan Tembakau Perahu Layar Ampenan.

\section{c) Metode Dokumentasi}

Metode dokumentasi adalah menelaan data-data yang tertulis atau berupa arsip-arsip yang ada dilokasi penelitian yang relevan dengan masalah yang diteliti.Teknik dokumentasi merupakan teknik pengumpulan data dengan mempelajari catatan-catatan mengenai data pribadi responden, arsip-arsip, suratsurat atau hal lainnya (fathoni, 2006:112).Maka adapun dokumen-dokumen yang dijadikan bahan dalam penelitian ini adalah jumlah anak yang tersangkut masalah hukum ketenagakerjaan.

\section{TEKNIK ANALISIS DATA}

Setelah data terkumpul selanjutnya diolah melalui tahap yang secara struktur, dengan mendeskripsikan atau melakukan preskriptif dan mensistematis data dan selanjutnya dianalisis sebagaimana lazimnya dan dipergunakan dalam penelitian hukum ialah melalui kajian yuridis atau peraturan perundang-undangan dan peraturan lain, dan kajian empiris untuk mengamati bagaimana reaksi dan interaksi masyarakat ketika peraturan itu diterapkan dan mengkaji tentang apa yang ada dibalik yang nampak dari penerapan peraturan perundang-undangan yang ada kaitannya dengan masalah yang akan diteliti.

Adapun menurut (Mukti Fajar, 2010: 25) tehnik analisis yang digunakan dalam penelitian ini adalah interprestasi hukum yakni:

1. Interprestasi prinsipial

Interprestasi prinsipial, adalah metode penafsiran untuk memahami hukum dengan cara menerima kesesuaian atas hukum yang ada.

2. Interprestasi sistematis

Penafsiran sistematis adalah dengan cara penafsiran suatu undang-undang sebagai bagian dari keseluruhan sistem perundangan dengan cara menghubungkan antara pasal yang satu dengan pasal yang lain dalam satu perundangundangan lainnya, atau membaca penjelasan agar dapat memahami maksudnya, serta mengkaji apa yang ada dibalik suatu yang nampak dari penerapan peraturan perundangundangan.

3. Interprestasi gramatikal

Interprestasi gramatikal adalah metode penafsiran dengan cara Menangkap arti atau makna dari peraturan perundang-undangan berdasarkan redaksi kalimat atau kata-katanya.

Berdasarkan uraian di atas maka dapat disimpulkan bahwa metode analisis bahan hukum yang digunakan dalam penelitian ini adalah metode normatif dan metode empiris. Analisis metode normatif dalam optik preskreptif dengan penalaran deduktif-induktif untuk menghasilkan proposisi atau konsep sebagai jawaban dari permasalahan atau hasil/temuan penelitian. Sedangkan analisis dengan metode empiris yaitu untuk memperoleh data mengenai tanggapan, perilaku sosial masyarakat yang timbul akibat interaksi dengan norma. Data tersebut dijadikan sebagai data pendukung dalam menjawsab permasalahan yang dihadapi.

\section{HASIL DAN PEMBAHASAN}

1. HASIL PENELITIAN

a) Pelaksanaan Perlindungan Hukum Terhadap Pekerja Anak Yang Bekerja Di Perusahaan Tembakau Perahu Layar Ampenan DI Tinjau Dari UU No 13 Tahun 2003.

\section{1) Hasil Observasi}

Hasil observasi tanggal 20 Agustus, bahwa kegiatan pekerja anak hampir menyebar merata pada perusahaan tembakau, hal tesebut disebabkan masingmasing keluarga dan anak terdesak oleh kebutuhan dalam hidupnya. Juga membantu ekonomi keluarga.Merujuk pada sampel penelitian, sebagian besar atau 36\% usia pekerja anak antara 10-12 tahun, usia pekerja anak umur 13 tahun berjumlah 8 orang atau 16\%, Usia 17 tahun berjumlah 8 anak atau 16\%. Usia 13 sampai 15 tahun berjumlah 8 atau 16\%, Usia 16 sampai 18 tahun berjumlah 7 anak atau 12\%. Data tersebut apabila ditabulasikan dapat diperoleh gambaran sebagai berikut.

Data Pekerja Anak Berdasarkan Kelompok Umur Di Perusahaan

\begin{tabular}{|c|c|c|c|}
\hline Nomor & Usia & $\begin{array}{c}\text { Jumlah } \\
\text { Pekerja }\end{array}$ & Prosentase \\
\hline 1 & 12 & 2 & $2 \%$ \\
\hline 2 & 13 & 5 & $14 \%$ \\
\hline 3 & 15 & 5 & $14 \%$ \\
\hline 4 & 17 & 7 & $15 \%$ \\
\hline
\end{tabular}

Tembakau Perahu Layar Ampenan

Sumber: Data Perusahaan Tembakau Perahu Layar Ampenan 2015

Berdasarkan data penelitian dan hasil prosetase tersebut, dapat diperoleh informasi bahwa terdapat pekerja anak yang usianya dibawah 15 tahun sebanyak $72 \%$, dan yang di atas 15 tahun hanya $28 \%$, anak-anak tersebut sebenarnya tidak layak untuk bekerja, sebab anak-anak tersebut seharusnya masih berada pada pendidikan sekolah. Kondisi faktual ini sebenarnya tidak sesuai dengan prinsip-prinsip perlindungan hukum terhadap anak, baik yang diatur di dalam Undangundang Ketenagakerjaan Nomor 13 Tahun 2003,UU No.39 Tahun 1999 Tentang Hak Asasi Manusia,UU No.23 Tahun 2002 Tentang Perlindungan Anak, UU No.4 Tahun 1979 Tentang Kesejahteraan Anak, serta prinsip-prinsip perlindungan anak menurut dilatik migran (ILO), maupun Konvensi Hak Anak. Berkaitan dengan latar belakang pendidikan pekerja anak, diperoleh informasi bahwa anak yang berstatus siswa sekolah dasar berjumlah 16 anak atau 32\%, Tamat SD sebanyak 10 orang dan tidak melanjutkan ke SMP atau $20 \%$, siswa SMP berjumlah 14 anak atau $28 \%$, sudah tamat SMP dan tidak melanjutkan SMA sebanyak 3 orang atau $6 \%$ dan pekerja anak siswa SMA berjumlah 3 anak atau $6 \%$. 
Berkaitan dengan status pendidikan maka dapat dilihat pula dari status pekerja anak yang tidak melanjutkan sekolah. Tidak melanjutkan sampai tamat sekolah dasar berjumlah 2 anak atau 4\%, tidak melanjutkan sampai sekolah lanjutan pertama berjumlah 2 anak atau 4\%. Berdasarkan hasil data penelitian tersebut dapat dikatakan bahwa 66\% pekerja anak masih berstatus sekolah, dari ditingkat SD, SMP, sampai dengan SMA, sedangkan 34\% para pekerja anak tersebut dapat dikategorikan sudah lulus SD dan DO SD, serta lulus SMP dan DO SMP.

Berdasarkan data penelitian terhadap anak yang bekerja sebagaimana dipaparkan diatas,maka dapat disimpulkan bahwa anak-anak yang bekerja di Perusahaan Tembakau Perahu Layar Ampenan.Penelitian bahwa sebanyak 50\% anak masih dalam status sekolah dari tingkat SD, SMP, dan SMA, sedangkan sebanyak $28 \%$ hanya tamat SD dan SMP dan sudah tidak melanjutkan sekolah (drop out).Hasil penelitian tersebut dapat diinter pretasikan bahwa, bekerja sebagai berikutnya pekerja anak yang bekerja di pabrik rokok, sebanyak $46 \%$.

Berdasarkan penelitian yang telah saya lakukan pada Perusahaan Tembakau Perahu Layar Ampenan, pada dasarnya pengusaha tidak merekrut pekerja anak sebagai pekerja tetapi karena faktor ekonomi dan budaya di sekitar yang mempengaruhi kondisi anak untuk melakukan pekerjaan di perusahaan tersebut.

\section{a. Hasil Wawancara}

Kepala Perusahaan Tembakau Perahu Layar Ampenan Bapak Sukamto mengatakan bahwa;

" pekerja anak saat ini yang bekerja di perusahaan merupakan keinginan mereka sendiri dan dorongan dari orang tua karena faktor ekonomi untuk membantu ekonomi keluarganya dan faktor kebudayaan yang berkeinginan memegang dan mendapatkan uang sendiri untuk melansungkan kehidupannya”.(Wawancara, 20 Agustus 2015)

Kemudian dari hasil wawancara diatas bahwa pihak perusahaan melakukan perjanjian kerja dengan pekerja anak secara lisan. Pihak perusahaan tidak memenuhi persyaratan untuk mempekerjakan anak yang sesuai dengan pasal 69 ayat 2 huruf b. Dari penjelasan diatas terlihat bahwa perlindungan anak dari eksploitasi ekonomi merupakan bagian dari hak terhadap kelangsungan hidup (survival rights). Lebih lanjut konvensi juga menentukan langkah-langkah yang harus diambil, yaitu antara lain; menentukan umur minimum atau umur-umur minimum untuk ijin bekerja, menetapkan peraturan-peraturan yang tepat mengenai jam-jam kerja dan syarat-syarat perburuhan, dan menentukan hukuman atau sanksi-sanksi lain yang tepat untuk menjarnin pelaksanaannya yang efektif.

Kemudian wawancara dengan bapak Supriadi selaku manajer mengatakan bahwa;

"Bahwa untuk lebih terlindunginya perkembangan anak secara teratur maka diperlukannya pembatasan waktu terhadap pekerja anak yang bekerja di Perusahaan Tembakau Perahu Layar Ampenan karena anak memerlukan aktifitas lain seperti bermain, waktu sekolah, belajar serta istrahat.Untuk mengetahui waktu kerja yang diberlakukan oleh Perusahaan Tembakau Perahu Layar Ampenen.pihak perusahaan mempekrjakan pekerja anak bekerja selama 3 jam sehari, dengan
Vol. 4, No. 2, September 2016, hal 11-21

pengaturan 1,5 jam kerja, 1/2 jam istirahat, dan 1 jam kerja". (Wawancara, 20 Agustus 2015)

1. Pelaksanaan perlindungan hukum yang dilakukan di perusahaan Tembakau Perahu Layar Ampenan adalah: Pengawasan terhadap pekerja anak hendaknya menjadi prioritas utama, agar perlindungan terhadap hak-hak anak dapat diwujudkan sebagai bentuk tanggung jawab perusahaan. Perlindungan anak menjadi tanggung jawab berbagai institusi dan lintas sektor. Oleh karena itu pelaksanaannya harus dapat dikoordinasikan secara baik, baik tingkat pusat maupun daerah sehingga terjadi keterpaduan dan sinergis dalam penanganannya. Bertanggung jawab terhadap perlindungan pekerja anak telah berupaya semaksimal mungkin untuk memberikan perlindungan pekerja anak

2. Pengaturan waktu kerja anak pada perusahaan Tembakau Perahu Layar Ampenan adalah:

Setiap pekerja anak berhak atas istirahat antara jam kerja dalam sehari-hari, sekurangkurangnya $1 / 2$ jam setelah bekerja 4 jam terus menerus dan waktu istirahat tersebut tidak termasuk jam kerja. Selain itu, pengusaha wajib memberikan waktu secukupnya bagi pekerja untuk melaksanakan makan siang yang diberikan oleh perusahaan satu jam, namun sebagian besar perusahaan memeberikan waktu istirahat satu jam.

Dari hasil wawancara diatas menunjukkan bahwa perusahaan Tembakau Perahu Layar Ampenan tidak memperhatikan perkembangan, kesehatan, mental pada pekerja anak. Hal ini terbukti lamanya pekerja anak bekerja di perusahaan tembakau perahu layar ampenan dalam sehari yaitu mulai jam $08.00 \mathrm{~s} / \mathrm{d}$ 16.30. Seharusnya para pekerja anak diberikan waktu yang sesuai dengan amanat Undang- undang No 13 Tahun 2003 tentang Ketenagakerjaan serta hak- hak anak itu sendiri mengingat tubuh dan mental dari anak itu sangat lemah dan dapat menghambat tumbuh kembangnya dari pekerja anak. Pekerja anak diberi waktu bekerja sama seperti orang dewasa pada umumnya maka dalam hal ini Perusahaan Tembakau Perahu Layar Ampenen melanggar pasal 69 ayat 2 huruf c dan d

Kemudian wawancara dengan salah satu pekerja anak (Arifudin) mengatakan bahwa;

Saya masih sekolah kelas II SMP dan saya melakukan pekerjaan di perusahaan Tembakau ini hanya pada hari libur yaitu hari libur saja, dan kita mulai bekerja dari jam o8 s/d 16.0o. saya meminta izin dengan orang tua saya untuk bekerja mengisi waktu hari libur. (Wawancara, 21 Agustus 2015)

Dari hasil wawancara diatas bahwa pihak perusahaan tidak mempekerjakan pekerja anak pada siang hari dan tidak mengganggu waktu sekolah. Karena pekerja anak yang terdapat diperusahaan sudah tidak sekolah. Pihak perusahaan tidak memenuhi persyaratan untuk mempekerjakan anak yang sesuai dengan pasal 69 ayat 2 huruf $d$.

3. Pekerja anak yang aktif sekolah adalah:

Perusahaan mempekerjakan pekerja anak dari pagi jam 07.00 s/d 16.00 sama seperti pekerja pada umumnya karena semua pekerja anak yang bekerja di perusahaan bekerja hari minggu jadi tidak mengganggu waktu sekolah, jadi dengan kondisi perusahaan sudah menjalankan sistem waktu pekerjaan yang sudah sesuai.pengusaha tidak sembarang mempekerjakan pekerja anak pada 
perusahaannya, pekerja anak melakukan pekerjaan hanya pada hari libur saja.

Berdasarkan wawancara dengan Bapak Lalu Husni selaku koordinasi mengatakan bahwa;

"Bahwa untuk mengetahui jaminan kecelakaan dan kesehatan kerja oleh Perusahaan Tembakau Perahu Layar Ampenan tentang Jaminan Sosial Tenaga Kerja dan Undang- undang Nomor 1 Tahun 1970 tentang Keselamatan Kerja Jaminan sosial yang ada pada Perusahaan Tembakau Perahu Layar Ampenan yaitu Jaminan kecelakaan dan kematian. Jaminan tersebut itu diberikan ketika ada pekerja yang mengalami kecelakaan. Semua pekerja yang bekerja di perusahaan tidak memakai perlengkapan kerja.Selain itu, di Indonesia masih sangat kurang sekali lembaga-lembaga yang bisa melakukan rehabilitasi terhadap anak dapat tumbuh dan berkembang dengan wajar baik secara rohani, jasmani maupun sosial khususnya anak yang mempunyai masalah, antara lain anak yang tidak mempunyai orang tua dan terlantar, anak terlantar, anak yang tidak mampu, anak yang mengalami masalah kelakuan, dan anak cacat. Usaha ini dimaksudkan memberikan pemeliharaan, perlindungan, asuhan, perawatan dan pemulihan kepada anak yang mempunyai masalah".(Wawancara, 21 Agustus 2015)

\section{Apa Saja Hambatan Perlindungan Hukum Terhadap Pekerja Anak yang Bekerja di Perusahaan Tembakau Perahu Layar Ampenan.}

\section{a. Hasil Observasi}

Berdasarkan hasil observasi yang saya lakukan pada tanggal 20 Agustus 2015 di perusahaan tembakau perahu layar Ampenan, permasalahan pekerja anak, secara factual memang tidak muda di tanggulangi, karena selalu di hadapkan pada perbedaan pandangan berkaitan dengan masalah pekerja anak, perbedaan pandangan demikian di dasari oleh perbedaan latar belakng pendidikan, kepentingan, nilai-nilai sosial kepribadian, dan persepsi masing-masing anggota masyarakat: terutama terhadap keberadaan pekerja anak tersebut. Berkaitan dengan peran masyarakat dalam rangka perlindungan hukum terhadap pekerja anak, dapat dikemukakan argumentasi bahwa keberhsilan usaha perlindungan pekerja anak sedikit banyak bergantung dan dipengaruhi kesetiaan dan kemampuan seorang anak untuk memperjuangkan dirinya sendiri dan kepentingan orang lain. Hal ini berkaitan sikap dan tindakan seseorang yang berhubungan erat dengan kerelaan seseorang untuk mengutamakan kepentingan orang lain, dalam hal ini pekerja anak diatas kepentingan pribadi.

Berdasarkan keyakinan, bahwa apabila pada akhirnya pelayanan kepentingan pekerja anak terpenuhi, maka kepentingan nasional juga akan terpenuhi, yang pada akhirnya berdampak pada pemenuhan kepentingan pribadi. Keyakinan tersebut apabila tidak dipahami oleh seluruh anggota masyarakat, maka dikwartikan banyak anggota masyarakat tidak akan merasa kewajiban untuk ikut serta dalam mengembangkan kemampuan anak untuk melindungi dirinya sendiri secara wajar dan legal, serta memeperhatikan kepentingan orang lain, orang dan bangsanya.
Perlindungan pekerja anak merupakan fenomena hasil interaksi antara anggota masyarakat di satu pihak, serta dengan unsur-unsur lain yang terlibat dalam hubungan ketenagakerjaan.unsur- unsure tersebut saling berhubungan atau melakukan interaksi dan interkoneksi dan bekerja sama secara simbiosis mutalisme, saling memepengaruhi dan dipengaruhi.kegiatan perlindungan pekerja anak akan terlambat dan akibatnya ketertiban, keamanan dan pembangunan nasional akan tergannggu tanpa adanya kerja sama dan koordinasi yang baik antara pihak yang terkait, perlu diketahui bahwa hambatan yang disebabkan karena tidak adanya kerja sama yang memuaskan antara instansi, badan organisasi pemerintah maupun swastapada masa lampau yang berkelanjutan maka permaslahan tersebut terus berlangsung sampai dengan saat ini dan keburukan ini mungkin akan berlangsung terus, apabila tidak di tangani secepat mungkin.

Dalam pelaksanaan perlindungan hukum terhadap pekerja anak yang bekerja di perusahaan tembakau tidak terlepas dari hambatan yang terjadi dalam proses perlindungan baik dari dalam perusahaan atau internal dan hambatan dari luar perusahaan atau eksternal. Hambatan-hambatan yang terjadi di Perusahaan Tembakau Perahu Layar Ampenan.

1. Hambatan dari Internal

a. Kontrak perjanjian kerja antara perusahaan dengan pihak Pemda yang mensyratkan jumlah pekerja yang harus dipenuhi sehingga perusahaan merekrut pekerja sesuai jumlah kebutuhan yang terdapat pada kontrak perjanjian sehingga tidak melihat pekerja yang masih tergolong anak.

b. Sumber Daya Manusia (SDM) yang ada pada perusahaan yang minim pendidikannya sehingga tidak tahu akan perlindungan hukum terhadap pekerja anak.

c. Pekerjaan di perusahaan dirasa cukup berat karena bergerak dibidang konstruksi sehingga secara tidak langsung pekerja anak yang bekerja melakukan pekerjaan berat.

2. Hambatan dari Eksternal

a. Tidak ada pengawasan dari pihak Disnaker yang menyebabkan perusahaan tidak tahu dan kurang maksimalnya perlindungan hukum terhadap pekerja anak.

b. Belum ada tenaga pengawasan dalam dinasnaker.

c. Faktor budaya di lingkungan pekerja anak yang mengakibatkan banyaknya pekerja anak yang bekerja di perusahaan tembakau.

d. Keinginan anak yang bekerja merupakan hambatan bagi perusahaan karena perusahaan tidak bisa menolak ketika anak meminta pekerjaan untuk membantu ekonomi orang tuanya serta keinginan orang tua dari pekerja anak yang menginginkan anaknya bekerja diperusahaan Tembakau Perahu Layar Ampenan.

\section{b. Hasil Wawancara.}

Kepala Perusahaan Tembakau Perahu Layar Ampenan Bapak Sukamto mengatakan bahwa;

"Bahwa bentuk perlindungan yang dilakukan oleh perusahaan terhadap pekerja anak, dalam memberikan pelaksanaan perlindungan hukum 

Perahu Layar Ampenan, karena dengan keseadaran hukum pengusaha maupun kesadaran hukum dari masyarakat pekerja terkait dengan pekerja anak adalah kesadaran hukum dari orang tua atau dari wali pekerja anak. Sebagaimana diketahui bahwa dalam memeperkerjakakan anak harus di lengkapi dengan syarat-syarat bagaimana telah di atur dalam Undang-Undang, namun dalam praktek banyak sekali hubungan kerja yang tidak di dasari dengan persyaratan yang telah ditentukan tersebut, terutama terkait dengan perjanjian kerja, jam kerja, izin orang tua atau wali.(Wawancara, 23 Agustus 2015)

Pelanggaran ini semata-mata disebabkan oleh adanya anggapan yang kurang pentingterhadap persyaratan kerja sebagaiman dimaksud dalam ketentuan pasal 69 ayat (2) Undang-Undang Ketenagakerjaan, baik dari pengusaha, maupun anak yang bekerja. Kondisi ini mengakibatkan bangsa Indonesia berada dalam "keadaan tak terpengharapan", karena pelanggaran hukum senantiasadilakukan terus menerus atau menjadi kebiasaan dan di anggap sebagai hal biasa dan pantas, keadaan ini dapat dikatakan budaya atau kultur yang berada di dalam kondisi yang menyedihkan.

Kemudian dalam wawancara dengan Bapak Supriadi, selaku manajer mengatakan bahwa;

"Perlindungan hukum terhadap pekerja anak diantaranya menyangkut belum adanya peraturan perundangan yang mengatur tentang pekerja anak sektor informal, khususnya terkait dengan perlindungan hukumnya, juga disebabkan oleh faktor aparatur pemerintah sebagai pengawas ketenagakerjaan, terutama jumlahnya yang lebih sedikit dibandingkan dengan perusahaan yang harus diawasi, tidak adanya pelaporan berkala dari perusahaan terhadap kondisi ketenakerjaan di perusahaan, kurang terbukanya perusahaan terhadap kondisi ketenagakerjaan teru tama apabila dilakukan sidak, serta kultur budaya yang memandang bahwa anak yang bekerja dipandang sebagai halyang biasa sebagai bentuk sosialisasi dan wujud darma bakti pada orang tua. Masyarakat kurang peduli, terutama dalam menyikapi penggunaan pekerja anak oleh perusahaan. (Wawancara, 23 Agustus 2015)

3. Hambatan perusahaan dalam menerapkan perlindungan hokum pada pekerja anak pada perusahaan Tembakau Perahu Layar Ampenan adalah:

1. Bila terjadi perselisihan kepentingan diantara perusahaan pemberi jasa dengan pekerja belum ada ketentuan-ketentuan hukum yang mendorong terlaksananya perundingan kolektif yang harmonis antara pekerja dan pengusaha yang dilandasi prinsip-prinsip perilaku beritikad baik

2. Birokrasi Perusahaan untuk penyediaan Jasa Tenaga kerja yang masih berbelit-belit hal ini menyebabkan pengurusan menjadi sangat lamban dan berlarut-larut yang menimbulkan rasa enggan bagi Perusahaan dalam pengurusan terhadap pekerja.

3. Adanya perbedaan kepentingan yang bertolak belakang dari para pihak dikarenakan ada 3 (tiga) pihak yang berhubungan langsung dalam setiap

Vol. 4, No. 2, September 2016, hal 11-21

penandatanganan perjanjian kerjasama yaitu; perusahaan pemberi pekerjaan, perusahaan penerima pekerjaan dan pekerja dari perusahaanperusahaan tersebut, yang menyebabkan terjadinya perselisihan karena adanya pelanggaran terhadap isi perjanjian (cedera janji atau wanprestasi) dari para pihak.

4. Kondisi ekonomi politik yang tidak stabil, faktor ini memang tidak berpengaruh seketika tapi dalam waktu yang tidak terlalu lama akan berdampak. Yang mengakibatkan timbulnya kesulitan untuk memenuhi isi perjanjian, karena harga kontrak kerja yang telah dibuat tidak lagi sebanding dengan kondisi ekonomi.

5. Pendapatan Perusahaan Tembakau Perahu Layar yang terbatas, baik dari usaha penyediaan jasa tenaga kerja maupun usaha lainnya, membuat biaya-biaya untuk tenaga kerja pemeriksaan Peralatan kilang dibatasi. Kurangnya peralatan untuk pemeriksaan Rutin Peralatan, yang sebagian besar harus disediakan oleh Perusahaan Tembakau perahu Layar Ampenan dengan harga yang relatif mahal, menyebabkan pekerjaan belum dapat dilaksanakan dengan profesional.

6. Perusahaan pengguna jasa pekerja dengan karyawan tidak memiliki hubungan kerja secara langsung, sehingga semua permasalahan mengenai pekerja tetap menjadi tanggung jawab perusahaan Tembakau, dan perusahaan pengguna jasa dapat melakukan keberatan atas perbuatan karyawan yang dirasa tidak sesuai aturan perusahaannya, sehingga seluruh tanggung jawab berada pada perusahaan penyedia tenaga kerja.

\section{Dampak pekerja anak negatif dalam pekerja anak adalah:}

1. Dampak pekerjaan terhadap perkembangan fisik anak Secara fisik pekerja anak lebih rentan dibanding orang dewasa karena fisik mereka masih dalam masa pertumbuhan. Bekerja sebagai pekerja anak dapat mempengaruhi perkembangan kesehatan fisik mereka karena pekerjaan yang mereka lakukan dapat menimbulkan kecelakaan maupun penyakit. Dampak kecelakaan terhadap pekerja anak dapat berupa luka-luka atau cacat akibat tergores, terpotong, terpukul, terbentur dan lain-lain.

2. Dampak pekerjaan terhadap perkembangan emosi anak

Pekerja anak sering bekerja dalam lingkungan kerja yang memungkinkan terjadinya eksploitasi, berbahaya, merendahkan martabat, derajat dan terisolasi. Mereka sering menerima perlakuan yang sewenang-wenang, kasar dan diabaikan oleh majikan mereka dan pekerja dewasa lainnya. Dampak yang ditimbulkan berupa pekerja anak menjadi pemarah, pendendam, kasar terhadap teman sebaya atau yang lebih muda, kurang mempunyai rasa kasih sayang terhadap orang lain dan adanya perasaan empati terhadap orang lain.

3. Dampak pekerjaan terhadap perkembangan sosial anak

Pekerja anak yang tidak mendapat kesempatan untuk melakukan kegiatan seperti bermain, pergi kesekolah dan bersosialisasi dengan teman sebanyanya, tidak mendapat pendidikan dasar yang diperlukan untuk mengatasi masalah-masalah 
kehidupan, tidak mendapat kesempatan untuk berinteraksi dengan orang lain dan ikut berpartisipasi aktif di tengah masyarakat serta menikmati hidup secara wajar biasanya akan tumbuh menjadi anak yang pasif dan egois sehingga sering berdampak anak mengalami masalah didalam interaksi/ menjalin kerjasama dengan orang lain dan mereka kurang percaya diri atau merasa direndahkan.

\section{Dampak pekerja anak positif dalam pekerja anak adalah:}

Dampak negatif terhadap perkembangan anak tersebut, maka dapat dikatakan bahwa pekerja anak merupakan suatu masalah yang perlu mendapat perhatian berbagai pihak. Masalah pekerja anak bukanlah masalah yang memiliki faktor penyebab tunggal, sehingga penanganannya pun perlu melibatkan beberapa pihak yang berhubungan dengan anak. Pandangan yang mempermasalahkan pekerja anak juga dapat dilihat dari perspektif hak anak. Perspektif hak anak memandang bahwa hak anak merupakan bagian dari hak asasi manusia yang mendapatkan pengakuan dan perlindungan secara Internasional. Setiap anak tanpa terkecuali memiliki 4 hak dasar yang meliputi : hak atas kelangsungan hidup, hak untuk tumbuh kembang, hak untuk mendapatkan perlindungan dan hak untuk berpartisipasi. Hak untuk tumbuh kembang merupakan hak anak untuk memperoleh pendidikan, informasi, waktu luang, kegiatan seni dan budaya, kebebasan berfikir, berkeyakinan dan beragama serta hak anak cacat atas pelayanan, perlakuan dan perlindungan khusus.

\section{Upaya-upaya perlindungan yang dilakukan oleh perusahaan terhadap pekerja anak adalah:}

Upaya perlindungan hukum terhadap pekerja anak, seperti aparat penegak hukum, dan aparat pemerintah pada umumnya seolah membiarkan pelanggaran pelanggaran terhadap norma-norma hukum ketenagakerjaan dalam rangka memberikan jaminan perlindungan hukum terhadap pekerja anak. Pekerja anak tidak sedikit yang dituntut untuk bekerja lebih cepat dan harus benar, apabila melakukan kesalahan, selain dipotong upah kerja juga akan dimarahi oleh mandor Anak-anak yang bekerja umumnya mereka terpaksa terlibat dalam situasi yang kurang menyenangkan, tanpa perlindungan yang baik serta tidak pula memperoleh kompensasi yang memadai.

\section{PEMBAHASAN}

Berdasarkan deskripsi data di atas maka dapat dilakukan pembahasan bahwa Perlindungan hukum terhadap pekerja anak tidak dapat dilepaskan dengan hak asasi anak sebab secara konstitusional Indonesia telah mengakui hak untuk bekerja dalam Pasal UUD 1945 yang dimasukkan pada klasifikasi hak yang bersifat asasi. Pengaturan terhadap hak asasi ini dituangkan dalam UU No.39 Tahun 1999 tentang Hak Asasi Manusia. Ketentuan Pasal 1 ayat (1) mengatur mengenai pengertian Hak Asasi Manusia, yaitu:Seperangkat hak yang melekat pada hakekat dan keberadaan manusia sebagai mahluk Tuhan Yang Maha Esa dan merupakan anugrah-Nya yang wajib dihormati, dijunjung tinggi oleh negara, hukum pemerintah dan setiap orang, demi penghormatan serta perlindungan harkat dan martabat manusia. Berdasarkan kualitas jaminan hak-haknya, UUD 1945 hasil amandemen mengatur jauhlebih lengkap dibandingkan sebelum amandemen, dari 5 pasal menjadi setidaknya 17 pasal (dengan 38 substansi hakhak yang beragam) yang terkait dengan hak asasi manusia.

Di dalam perusahaan terdapat seorang pekerja anak yang bekerja dengan orang tuanya. Dan perusahaan mempekerjakan pekerja anak di Perusahaan Tembakau Perahu Layar Ampenan. 11 anak yang bekerja di perusahaan itu bukan merupakan perekrutan dari perusahaan melainkan orang tuanya yang bekerja di perusahaan dan membawa anaknya untuk membantu dan itu tidak menguntungkan sama sekali ke perusahaan. Tetapi karena perusahaan merasa kasihan dengan keadaan keluarganya maka perusahaan memperbolehkan untuk bekerja dan pekerja anak tersebut di perlakukan sama dengan pekerja yang lain. Jadi secara tidak langsung pekerja anak perjanjian kerja antara orang tua dan pengusaha sudah terwakilkan oleh orang tuanya. Sedangkan pekerja anak yang lain dan yang masih sekolah perjanjian kerjanya langsung kepada anak itu sendiri tetapi secara lisan bukan tulisan dengan menjelaskan apa yang menjadi pekerjaan dari pekerja anak. Dan pada akhirnya perusahaan karena merasa kasihan pekerja anak tersebut bekerja di perusahaan.

Undangundang No.13 Tahun 2003 tentang ketenagakerjaan mengenai waktu bekerja bagi pekerja anak. Penulis menemukan pelanggaran itu disebabkan karena faktor ketidaktahuan kontraktor terhadap perlindungan hukum dan hak-hak dari pekerja anak. Pekerja anak yang ada di perusahaan itu dibawa oleh orang tuanya untuk melakukan pekerjaan. Sedangkan pekerja anak yang lain itu meminta sendiri ke perusahaan untuk mendapatkan pekerjaan agar mereka mempunyai uang sendiri. Tetapi perusahaan tidak sembarangan untuk mempekerjakan anak karena perusahaan juga melihat fisik anak yang bisa dipekerjakan. Dan faktor ekonomi juga mempengaruhi anak menjalankan pekerjaan sebagai pekerja anak di perusahaan Tembakau Perahu Layar Ampenan guna membantu ekonomi keluarganya serta keinginan anak itu sendiri untuk belajar mencari uang. Dengan pertimbangan seperti perusahaan tembakau perahu layar ampenan itu mempekerjakan mereka.Selain memperhatikan ketiga pendekatan tersebut diatas, upaya memberikan perlindungan dan pencegahan terhadap pekerja anak dapat dilakukan dengan cara; pertama, mengubah persepsi masyarakat terhadap pekerja anak, bahwa anak yang bekerja dan terganggu tumbuh kembangnya dan tersita hak-haknya akan pendidikan tidak dapat dibenarkan. Kedua, melakukan advokasi secara bertahap untuk mengeliminasi pekerja anak, dengan perhatian pertama diberikan kepada jenis pekerjaan yang sangat membahayakan, dalam hal ini perlu ada kampanye besar-besaran untuk menghapuskan pekerja anak. Ketiga, mengundangkan dan melaksanakan peraturan Perundang-undangan yang selaras dengan konvensi internasional, khususnya Konvensi Hak Anak dan Konvensi ILO lain yang menyangkut anak, keempat, mengupayakan perlindungan hukum dan menyediakan pelayanan yang 
20 CIVICUS I Pendidikan Pancasila dan Kewarganegaraan memadai bagi anak-anak yang bekerja di sektor informal, seperti di tempat pembuangan akhir (TPA) sampah. Kelima, memastikan agar anak-anak yang bekerja memperoleh pendidikan dasar 9 tahun, pendidikan keterampilan melalui bentu-bentuk pendidikan alternatif yang sesuai dengan kebutuhan mereka.

Perusahaan mempekerjakan pekerja anak pada hari libur saja dan tidak mengganggu waktu sekolah. Perusahaan mempekerjakan pekerja anak dari pagi jam o8.00 s/d 10.00 sama seperti pekerja pada umumya karena semua pekerja anak yang bekerja di perusahaan sudah tidak melanjutkan sekolah sebagian anak. Sedangkan pekerja anak yang masih sekolah bekerja hari minggu jadi tidak mengganggu waktu sekolah. Jadi dengan kondisi diatas perusahaan sudah menajalankan sistem waktu pekerjaan yang sudah sesuai. Berdasarkan pasal 69 ayat 2 huruf e Undangundang No.13 Tahun 2003 tentang Ketenagakerjaan khususnya yang mengatur tentang keselamatan dan kesehatan kerja, perusahaan kontraktor Perusahaan Tembakau Perahu Layar Ampenan dapat dikatakan kurang melindungi dan melanggar jaminan kesehatan dan keselamatan pekerja anak. Karena dalam hal ini Perusahaan Tembakau Perahu Layar Ampenan tidak memenuhi peraturan tentang pekerja anak yang telah diamanatkan Undang-undang Nomor 13 Tahun 2003 tentang Ketenagakerjaan yaitu: Jaminan Kesehatan bagi pekerja anak. dan Pasal 6 huruf d Undang-undang Nomor 3 Tahun 1992 tentang Jaminan Sosial yaitu jaminan pemeliharaan kesehatan. Serta Pasal 12 huruf b Undang-undang Nomor 1 Tahun 1970 tentang Keselamatan Kerja yaitu memakai alat-alat perlindungan diri yang diwajibkan Serta tidak terpenuhinya perlindungan seperti yang diamanatkan Pasal 8 Undang-undang Nomor 23 Tahun 2002 tentang Perlindungan Anak yaitu Setiap anak berhak memperoleh pelayanan kesehatan dan jaminan sosial sesuai dengan kebutuhan fisik, mental, spiritual, dan sosial.

Upaya perlindungan hukum pemerintah terhadap pekerja anak dilakukan dalam bentuk pembatasan jenis-jenis atau bentuk-bentuk pekerjaan yang dilarang untuk dikerjakan anak, dan mengenai hal ini dapat dilihat di dalam. Keputusan Presden No.59 Tahun 2002 tentang Bentuk-bentuk Pekerjaan Yang Dilarang untuk Anak, dan juga Surat Keputusan Menteri tenaga Kerja dan Transmigrasi Nomor Kep235/MEN/2003 tentang Jenis-jenis Pekerjaan yang Membahayakan Kesehatan,Keselamatan atau Moral Anak, yang pada prinsipnya melarang anak untuk bekerja pada jenis-jenis pekerjaan tertentu tersebut. Larangan pekerja anak ini, secara yuridis terkait dengan kewajiban pemerintah untuk melakukan pencegahan dan penanggulangan. Hal ini telah diatur di dalam UU Ketenagakerjaan, sebagaimana tertuang di dalam ketentuan Pasal 75, yaitu:

1. Pemerintah berkewajiban melakukanupaya penanggulangan anak yang bekerja di luar hubungan kerja;

2. Upaya penanggulangan sebagaimana dimaksud dalam ayat (1) diatur dengan Peraturan Pemerintah. Ketentuan Pasal 75 tersebut diantaranya ditindak lanjuti dengan peraturan khusus yang berkaitan dengan pengembangan bakat dan minat anak, yang diatur di dalam Keputusan Menteri Tenaga Kerja dan Transmigrasi Kep.115/MEN/VII/2004 tentang
Perlindungan Bagi Anak Yang Melakukan Pekerjaan Untuk Mengembangkan Bakat dan Minat, yang ditetapkan pada tanggal 7 Juli 2004. Faktor Kerjasama dan Koordinasi Perlindungan pekerja anak merupakan fenomena hasil interaksi antara anggota masyarakat di satu pihak dengan pengusaha di pihak lain, serta dengan unsur-unsur lain yang terlibat dalam hubungan ketenagakerjaan. Unsur-unsur tersebut saling berhubungan atau melakukan interrelasi dan interkoneksi dan bekerja sama secara simbiosis mutualisme, saling mempengaruhi dan dipengaruhi.Kegiatan perlindungan pekerja anak akan terhambat dan akibatnya ketertiban, keamanan dan pembangunan nasional akan terganggu tanpa adanya kerjasama dan koordinasi yang baik antara pihak yang terkait. Perlu diketahui, bahwa hambatan yang disebabkan karena tidak adanya kerjasama yang memuaskan antara instansi, badan, organisasi pemerintah maupun swasta pada masa lampau yang berkelanjutan, maka permasalahan tersebut terus berlangsung sampai dengan saat ini dan keburukan ini mungkin akan berlangsung terus, apabila tidak ditangani secepat mungkin.

Ada cara-cara lain dalam hal perlindungan terhadap pekerja anak, antara lain sebagai berikut:

1. Lemahnya penegakan hukum terhadap eksploitasi pekerja anak merupakan indikasi adanya sikap ambivalen pemerintah terhadap permasalahan ini, di samping juga rendahnya tingkat pengetahuan dan perhatian aparat penegak hukum. Peningkatan jaringan kerja sama LSM dalam melakukan advokasi perlindungan hukum terhadap pekerja anak sangat dibutuhkan untuk mendorong terjadinya keseimbangan antara hak dan kewajiban.

2. Salah satu cara lain dalam mengatasi permasalahan "pekerja anak", khususnya anak jalanan yaitu dengan jalan adopsi. Pengertian adopsi yaitu pengangkatan anak berusia balita yang dimana kondisi dalam kelangsungan hidupannya termasuk kondisi keluarga yang tidak mampu atau bisa juga sebab lain. Dalam perspektif HAM adopsi merupakan jalan terbaik guna menanggulangi dan mengurangi beban penderitaan masyarakat miskin maupun masyarakat anak jalanan itu sendiri karena anak-anak merupakan aset bangsa sebagai generasi penerus dan merupakan potensi sumber daya manusia bagi pembangunan nasional jangka pendek maupun jangka panjang.

3. Dibutuhkan pembinaan dan memberikan kesempatan kepada anak bangsa yang terlantar di jalanan yang dalam pendidikan kurang mendapatkan semestinya di usia belajar. Kondisi ini merupakan tugas kewenangan kita bersama sebagai kepanjangan tangan dari tugas negara untuk mengayomi khususnya pemerintah dan kita sebagai masyarakat Indonesia yang peduli atas kehadiran anak-anak tersebut untuk mengenyam pendidikan.

Masalah perlindungan hukum bagi pekerja anak bukan sesuatu yang dapat diatasi seperti membalikkan telapak tangan. Prosesnya akan memakan waktu yang lama serta membutuhkan kerja sama yang serius antara pemerintah pusat dengan pemerintah daerah, dan sejauh mana Negara telah memberikan perlindungan terhadap pekerja anak, masih perlu dipantau lebih lanjut. 


\section{SIMPULAN DAN SARAN}

1) KESIMPULAN

Dari hasil pembahasan dapat disimpulkan:

a) Perlindungan hukum terhadap pekerja anak yang bekerja di Perusahaan Tembakau Perahu Layar Ampenan. Tidak ada karena persyaratan yang ada dalam Undang-undang Nomor 13 Tahun 2003 tentang Ketenagakerjaan yang harus dipenuhi untuk mempekerjakan anak tidak memenuhi semuanya seperti pihak sperusahaan melakukan perjanjian kerja dengan pekerja anak secara lisan. Pihak perusahaan tidak memenuhi persyaratan perjanjian kerja untuk mempekerjakan anak yang sesuai dengan pasal 69 ayat 2 dan melanggar keputusan menteri no 235 tahun 2003 tentang jenis-jenis pekerjaan yang membahayakan kesehatan dan keselamatan anak atau moral anak.

b) Hambatan bagi perusahaan karena perusahaan tidak bisa menolak ketika anak meminta pekerjaan untuk membantu ekonomi orang tuanya serta keinginan orang tua dari pekerja anak yang menginginkan anaknya bekerja diperusahaan. Serta tidak ada pengawasan dari pihak Disnaker yang menyebabkan perusahaan tidak tahu dan kurang maksimalnya perlindungan hukum terhadap pekerja anak. Dan faktor budaya di lingkungan pekerja anak yang mengakibatkan banyaknya pekerja anak yang bekerja di perusahaan Pekerjaan di perusahaan dirasa cukup berat karena bergerak di perusahaan sehingga secara tidak langsung pekerja anak yang bekerja melakukan pekerjaan berat. Pihak perusahaan memberikan perlakuan khusus ketika bekerja sesuai dengan kemampuan pekerja anak. Memberikan jaminan dan kecelakaan kerja terhadap pekerja anak yang bekerja di Perusahaan Tembakau Perahu Layar Ampenan. Memberikan sosialisasi kepada pekerja anak yang bekerja di perusahaan tembakau.

\section{2) SARAN}

Dari hasil pembahasan memunculkan rekomendasi yaitu:

a) Mengadakan sosialisasi dari Disnaker terhadap terhadap masnyarakat akanpentingnya perlindungan hukum terhadap pekerja anak.

b) Adanya kesatuan tentang perlindungan pekerja anak dengan caramenyatukan peran pemerintah, masnyarakat, Orang tua, pengusaha untuk mencegah banyaknya pekerja anak.

c) Meningkatkan pengawasan dari Disnaker terhadap perusahaan yang mempekerjakan pekerja anak.

d) Memberikan sanksi yang tegas terhadap perusahaan yang melanggar hak-hak dari pekerja anak.

e) Memberikan sanksi kepada orang tua yang tidak patuh terhadap hukum tentang perlindungan anak yang bekerja di perusahaan Tembakau Perahu Layar Ampenan. 